\title{
IMPLEMENTASI ALGORITMA FISHER-YATES SHUFFLE PADA APLIKASI MULTIMEDIA INTERAKTIF UNTUK PEMBELAJARAN TENSES BAHASA INGGRIS
}

\author{
Beki Subaeki $^{1)}$, Dicky Ardiansyah ${ }^{2)}$ \\ Program Studi Teknik Informatika ${ }^{122}$ \\ Universitas Sangga Buana YPKP ${ }^{1)}$, UIN Sunan Gunung Djati ${ }^{2)}$ \\ Beki807@,gmail.com ${ }^{1)}$, dicky.ardiansyah55@gmail.com²)
}

\begin{abstract}
ABSTRAK
Bahasa Inggris adalah Bahasa Internasional sekaligus bahasa universal yang digunakan oleh berbagai negara di dunia. Hal ini membuat Bahasa Inggris juga menjadi bahasa asing yang sering kita pelajari dari jenjang sekolah dasar hingga perguruan tinggi. Dalam Bahasa Inggris, Time (waktu) sangat erat hubungannya dengan Tense (perubahan kata kerja). Sehingga mempelajari tenses, juga merupakan modal dasar bagi seseorang untuk menguasai konteks kalimat Bahasa Inggris. Dalam skripsi ini media penyampian informasi mengenai materi tenses dibuat dalam bentuk PBK (Pembelajaran Berbantuan Komputer), yakni Multimedia Interaktif. Multimedia Interaktif dapat memberikan sebuah interaktifitas antara pengguna dengan aplikasi. Interaktifitas yang dibuat dalam aplikasi pembelajaran tenses ini berupa simulasi soal untuk mengasah tingkat pemahaman materi tenses pengguna. Soal uji pemahaman dibuat ke dalam dua (2) ketegori, yakni soal latihan dan soal tes evaluasi menggunakan format penyimpanan data standar berbasis .XML (eXtensible Markup Language). Implementasi algortima acak (shuffling) pada pembuatan aplikasi digunakan untuk mengacak urutan soal uji pemahaman. Algoritma acak (shuffling) yang dipakai adalah algoritma Fisher-Yates Shuffle. Algoritma Fisher-Yates Shuffle dapat mengacak urutan data bank soal .xml yang dimasukkan kedalam array dan dipanggil menggunakan bahasa pemrograman ActionScript 3.0, sehingga soal yang diacak akan menghasilkan permutasi yang berbeda dan memiliki hasil bias.
\end{abstract}

Kata kunci : $\quad$ Tenses, PBK (Pembelajaran Berbantuan Komputer), Multimedia Interaktif, Soal Uji Pemahaman, .XML (eXtensible Markup Language), ActionScript 3.0, Algoritma Fisher-Yates Shuffle.

\section{PENDAHULUAN}

Bahasa Inggris adalah Bahasa Internasional sekaligus Bahasa Universal yang digunakan oleh berbagai Negara di dunia. Dalam Bahasa Inggris, Time (waktu) sangat erat kaitannya dengan Tense (perubahan kata kerja). Sehingga mempelajari Tenses, juga merupakan modal dasar bagi seseorang yang ingin dapat mengerti atau menguasai konteks kalimat dalam Bahasa Inggris.

Orang yang belajar atau menuntut ilmu, mendapat kehormatan di sisi Alloh dan Rosulnya. Sebagimana firman Alloh S.W.T:

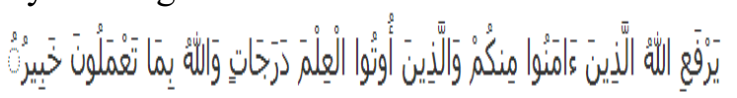

Artinya:

"Allah akan meninggikan orang-orang yang beriman di antaramu dan orang-orang yang diberi ilmu pengetahuan beberapa derajat" (Q.s. al-Mujadalah : 11)

Serta sabda Nabi Muhammad s.a.w:

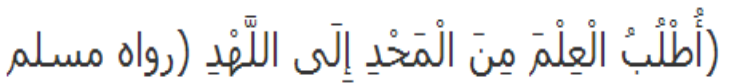

Artinya:

"Carilah ilmu dari buaian sampai liang lahat"(HR. Muslim)

Ilmu pengetahuan yang semakin berkembang dan Teknologi Komputer yang semakin maju ikut serta menghantarkan penyampaian Informasi melalui berbagai media, termasuk media Pembelajaran Berbantuan Komputer (PBK). Multimedia sebagai salah satu jenis Pembelajaran Berbantuan Komputer yang mampu memberikan simulation (simulasi) dan drill and practic (praktik dan latihan), menjadikan 
multimedia sebagai media penyampaian informasi yang dapat memberikan interaktifitas ke pengguna.

Soal uji pemahaman adalah bentuk dari simulation juga drill and practic, yang dapat dibuat dalam bentuk aplikasi Multimedia Interaktif. Karena soal uji pemahaman ini merupakan poin penting bagi pengguna aplikasi pembelajaran, agar dapat mengukur seberapa jauh tingkat pemahaman terhadap materi yang sedang dipelajarinya. Diperlukan cara atau jalan untuk mengubah urutan soal uji pemahaman, yakni dengan menggunakan algoritma. Algoritma ini harus dapat mengubah atau mengacak urutan soal uji pemahaman yang disajikan.

Algoritma acak (shuffling) Fisher-Yates Shuffle, dapat mengacak urutan suatu data yang dimasukkan kedalam array. Algoritma ini banyak digunakan dalam aplikasi permainan yang membutuhkan metode pengacakan, seperti permainan puzzle dan kartu. Karena algoritma ini bersifat bias (kecil kemungkinan tampil dengan urutan/posisi sama).

Peneliti: Ade-Ibijola, Abejide Olu. $A$ Simulated Enhancement of Fisher-Yates Algorithm for Shuffling in Virtual Card Games using Domain-Specific Data Structures, International Journal of Computer Applications, 2012.

"Memberikan informasi mengenai keberhasilan dari proses algoritma acak Fisher-Yates Shuffle dalam mengacak urutan data dan menghasilkan permutasi berbeda, yang disimulasikan ke dalam game kartu virtual".

(Sumber: https://www.academia.edu, diakses 22/10/2013, 05:55)

\section{Kerangka Pemikiran:}

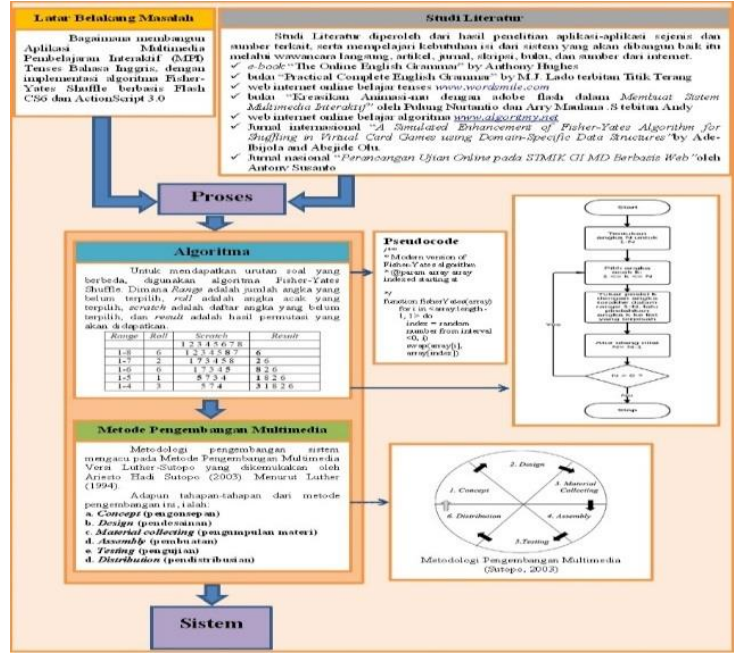

Gambar 1. Kerangka Pemikiran

\section{DASAR TEORI}

\section{Metode Pengembangan Multimedia}

Selanjutnya untuk metodologi pengembangan sistem mengacu pada Metode Pengembangan Multimedia Versi LutherSutopo yang dikemukakan oleh Ariesto Hadi Sutopo (2003). Menurut Luther (1994), metodologi pengembangan multimedia terdiri dari enam tahap, yaitu:

1. Pengonsepan (Concept)

2. Pendesainan (Design)

3. Pengumpulan Materi (Material collecting)

4. Pembuatan (Assembly)

5. Pengujian (Testing)

6. Pendistribusian (Distribution)

Keenam tahap ini tidak harus berurutan dalam praktiknya, tahap-tahap tersebut dapat saling bertukar posisi. Meskipun begitu, tahap concept memang harus menjadi hal yang pertama kali dikerjakan.

Sutopo (2003) mengadopsi metodologi Luther dengan modifikasi, seperti yang terlihat pada Gambar 2

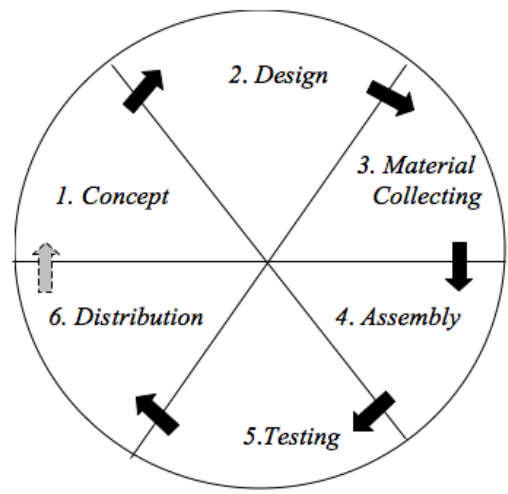

Gambar 2. Metodologi Pengembangan Multimedia (Sutopo, 2003)

\section{Pengonsepan (Concept)}

Tahap Pengonsepan (Concept) adalah tahap untuk menentukan tujuan dan siapa pengguna program (identifikasi audience). Selain itu menentukan macam aplikasi (presentasi, interaktif, dll) dan tujuan aplikasi (hiburan, pelatihan, pembelajaran, dll).

\section{Pendesainan (Design)}


Tahap Pendesainan (Design) adalah tahap membuat spesifikasi mengenai arsitektur program, gaya, tampilan dan kebutuhan material/bahan untuk program.

\section{Pengumpulan Materi (Material collecting)}

Tahap Pengumpulan Materi (Material collecting) adalah tahap dimana pengumpulan bahan yang sesuai dengan kebutuhan dilakukan. Tahap ini dapat dikerjakan paralel dengan tahap assembly. Pada beberap kasus, tahap Material Collecting dan tahap Assembly akan dikerjakan secara linear tidak paralel.

\section{Pembuatan (Assembly)}

Tahap assembly (pembuatan) adalah tahap dimana semua objek atau bahan multimedia dibuat. Pembuatan aplikasi didasarkan pada tahap design.

\section{Pengujian (Testing)}

Dilakukan setelah selesai tahap pembuatan (assembly) dengan menjalankan aplikasi/program dan dilihat apakah ada kesalahan atau tidak. Tahap ini disebut juga sebagai tahap pengujian alpha (alpha test) dimana pengujian dilakukan oleh pembuat atau lingkungan pembuatnya sendiri.

\section{Pendistribusian (Distribution)}

Tahapan dimana aplikasi disimpan dalam suatu media penyimpanan. Pada tahap ini jika media penyimpanan tidak cukup untuk menampung aplikasinya, maka dilakukan kompresi terhadap aplikasi tersebut.

\section{ICONCEPT DAN PERANCANGAN}

\section{Algoritma Fisher-Yates Shuffle}

Analisis algoritma Fisher-Yates Shuffle, dimaksudkan untuk memberikan gambaran konsep dari algoritma acak (shuffling) jika diterapkan pada Aplikasi Multimedia Tenses Bahasa Inggris. Analisis Algoritma Fisher-Yates Shuffle menggunakan array, dapat dilihat pada Gambar 3

\begin{tabular}{|c|c|c|c|c|c|c|}
\hline \multicolumn{5}{|c|}{ Kondisi Array } & \multirow{3}{*}{$\begin{array}{l}\begin{array}{c}\text { Satu data acak yang } \\
\text { diambil }\end{array} \\
\mathrm{C} \\
2 \\
\end{array}$} & \multirow{3}{*}{\begin{tabular}{|l|}
\multicolumn{1}{|c}{ Keterangan } \\
$\begin{array}{l}\text { Semua data di sebelah } \\
\text { kanan C bergeser satu } \\
\text { kali ke kiri. }\end{array}$ \\
\end{tabular}} \\
\hline A & B & C & D & E & & \\
\hline 0 & 1 & 2 & 3 & 4 & & \\
\hline A & B & D & E & & \multirow{3}{*}{$\begin{array}{l}\text { Isikan data selain } \\
\text { yang sudah diambil. } \\
\text { Berikutnya, nomor } \\
\text { indeks dapat } \\
\text { disesuaikan lagi. }\end{array}$} & \multirow{3}{*}{$\begin{array}{l}\text { Dan begitu seterusnya } \\
\text { sampai data tinggal } \\
\text { satu buah. }\end{array}$} \\
\hline 0 & 1 & 2 & 3 & & & \\
\hline & & & & & & \\
\hline
\end{tabular}

Gambar 3. Analisis algoritma menggunakan array

Dari Gambar 3, diketahui bahwa array pertama berukuran 5 (berisi 5 buah data), diberi indeks atau nomor mulai dari 0 sampai 4. Berikutnya buat array baru dengan menimpa array lama,ukurannya $\mathrm{N}-1$.

Dalam proses pengacakan, Algoritma Fisher-Yates Shuffle akan dijelaskan menggunakan Flowhart. Akan dijelaskan pada Gambar 4.

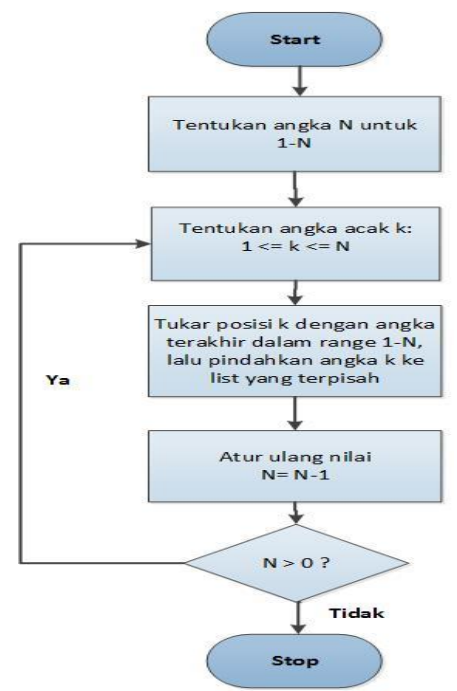

Gambar 4. Flowchart Algoritma Fisher-Yates Shuffle

Dari Gambar 4, diketahui bahwa algoritma Fisher-Yates Shuffle dalam mnegacak urutan data diawali dengan menentukan angka $\mathrm{N}$ untuk range 1-N. Setelah itu tentukan angka acak $\mathrm{k}$ dari range 1-N, tidak boleh 0 dan melebihi nilai $\mathrm{N}$. Tukar posisi $\mathrm{k}$ dengan angka terakhir range 1-N ditempat terpisah. Atur ulang $\mathrm{N}, \mathrm{N}=1$. Jika $\mathrm{N}$ bernilai 0 , maka hentikan proses pengacakan.

Berikut penjelasan dalam bentuk tabel urutan soal. Terdapat 5 buah soal dalam bank soal XML, dimana urutanya ter-urut dari 1-5. Akan di suffling (acak), sehingga urutan yang ditampilkan akan berbeda. Range adalah jumlah angka yang belum terpilih, Roll adalah angka acak yang terpilih, Scracth adalah daftar angka yang belum terpilih, dan Result adalah hasil permutasi yang didapatkan. Untuk mengetahui analisis pengacakan urutan soal, Perhatikan Tabel 1: 
Tabel 1. Analisis pengacakan urutan soal

\begin{tabular}{|l|l|l|l|}
\hline Range & Roll & Scracth & Result \\
\hline & & 12345 & \\
\hline $1-5$ & 4 & $123 \mathbf{5}$ & $\mathbf{4}$ \\
\hline $1-4$ & 2 & $1 \mathbf{5 3}$ & $\mathbf{2} 4$ \\
\hline $1-3$ & 3 & $1 \mathbf{5}$ & $\mathbf{3 2} 4$ \\
\hline $1-2$ & 2 & $\mathbf{1}$ & $\mathbf{5 3} 24$ \\
\hline
\end{tabular}

Dari tebel diatas, maka didapatkan hasil permutasi 15324 . Sehingga walaupun urutan soal dibank soal XML berurut, namun akan ditampilkan berbeda oleh program pada halaman Soal Latihan dan Tes. Untuk lebih jelas dalam memahami proses mengacak (shuffling) urutan pada form soal. Perhatikan Gambar 5:

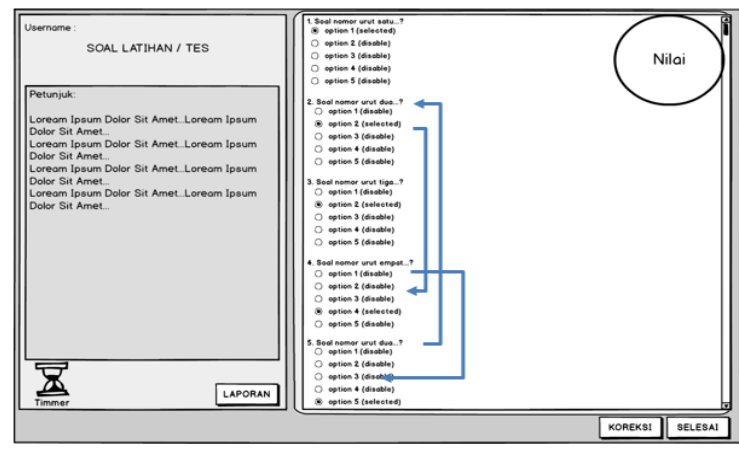

Gambar 4. Halaman Soal Latihan/Tes

Dengan melihat alur algoritma menggunakan flowchart dan tabel konsep pengacakan urutan soal, berikut adalah analisis pseudocode dari algoritma Fisher-Yates Shuffle. Perhatikan Gambar 6:

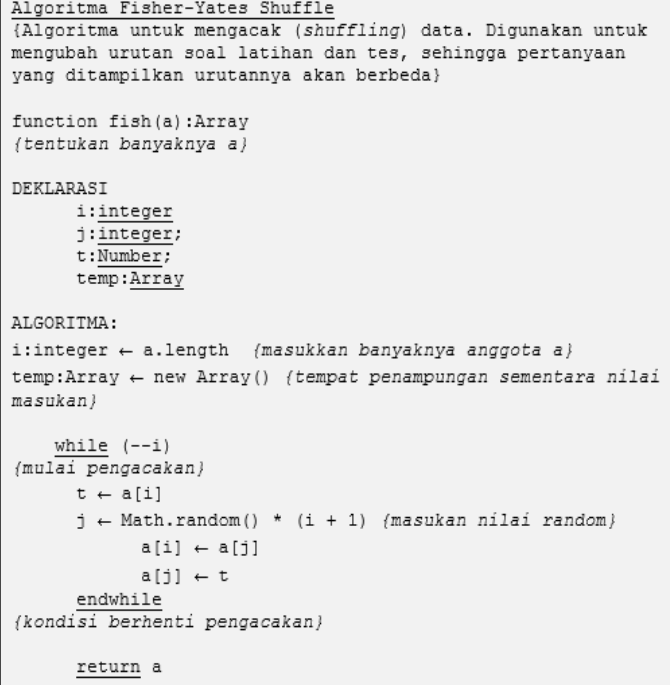

Gambar 6 Pseudoode Algoritma FisherYates Shuffle

Fungsi fish(a) bertipe array dengan parameter a sebagai nilai masukkan yang akan diacak. Algoritma diatas dilanjutkan oleh deklarasi yaitu $i$ sebagai integer (untuk memasukkan nilai banyaknya anggota $a$ ), $j$ sebagai integer, $t$ sebagai number, dan temp sebagai Array sementara untuk menampung nilai masukkan.

Kemudian dilanjutkan dengan alur algoritma yang melakukan pengulangan while dengan kondisi jika -- $i$ adalah benar. Pada algoritma tersebut, dilakukan penukaran antara $t, j$ dan $a$. $t$ dimasukkan anggota $a$ ke- $i, j$ dimasukkan nilai random, nilai $a[i]$ dimasukkan nilai $a[j]$, sedangkan $a[j]$ dimasukkan nilai $t$.

Pengulangan while tersebut berakhir ketika --i bernilai false (bernilai kurang dari 0). Setelah nilai teracak, maka akan dikembalikan melalui return a.

\section{Arsitektur Sistem}

Arsitektur sistem adalah istilah untuk menyatakan bagaimana mendefinisikan konsep dari komponen-komponen yang lebih spesifik secara terstruktur dalam menggambarkan alur sistem dan pengguna. Arsitektur sistem dari Aplikasi Multimedia Interaktif Pembelajaran Tenses Bahasa Inggris ini, dapat dilihat pada Gambar 7:

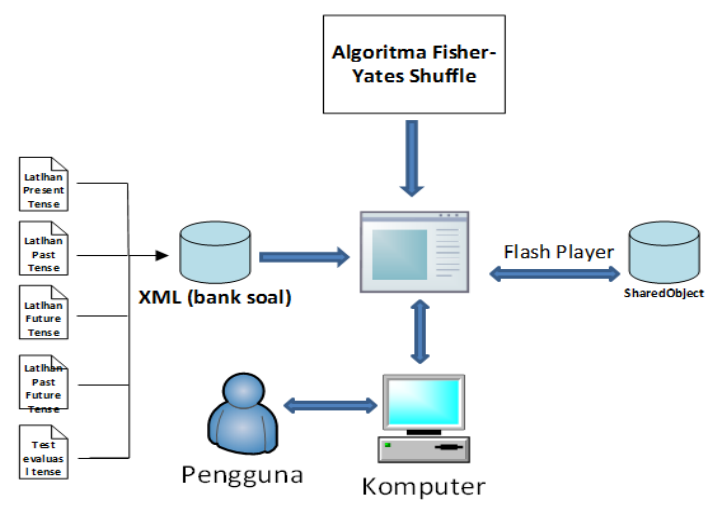

Gambar 7. Arsitektur Sistem

Arsitektur sistem di atas dapat dijelaskan sebagai berikut:

1. Algoritma Fisher-Yates Shuffle diimplementasikan untuk 
mengacak (shuffling) soal dari XML.

2. $X M L$ berfungsi sebagai format penyimpanan data standar untuk menyimpan bank soal latihan dan tes evaluasi.

3. SharedObject dibuat untuk save dan update username username dari form Pilih User serta skor nilai dari Form Soal Latihan dan Tes.

4. Aplkasi Multimedia Pembelajaran Interaktif Tenses Bahasa Inggris ditampilkan oleh Flash Player yang terinstal di komputer.

5. Pengguna berinteraksi langsung dengan komputer secara stand alone yang berarti aplikasi tidak terhubung ke jaringan ataupun server, karena Aplikasi Multimedia ini bersifat SharedObject.

\section{Bank Soal}

Sedangkan untuk kebutuhan data pada aplikasi multimedia ini, akan dibuat bank soal yang disimpan dalam bentuk file .xml yang merupakan format penyimpanan data standar. Perhatikan Gambar 8:

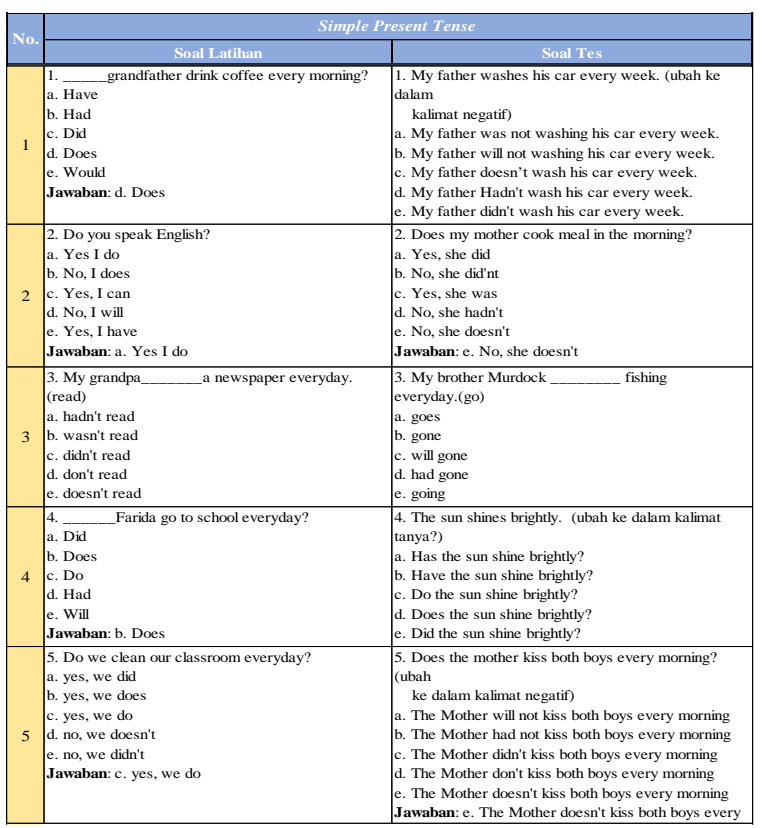

Gambar 8. Bank Soal

Akan dibuatkan sebanyak delapan puluh (80) soal latihan yang akan dibagi menjadi empat (4) sub soal latihan tenses berdasarkan materi yang dipelajari. Sedangkan untuk soal tes berjumlah delapan puluh (80). Jadi total keseluruhan bank soal Aplikasi Multimedia Tenses ini, adalah seratus enam puluh (160) soal.

\section{IMPLEMENTASI DAN PENGUJIAN}

\section{Pengujian Antarmuka (Interface)}

Pengujian antarmuka (interface) dilakukan untuk mengetahui, apakah interface yang dirancang pada tahap Design (pendisainan) dan Material Collecting (pengumpulan materi) sudah sesuai dengan tujuan pembuatan perangkat lunak.

a. Interface Main Menu

Tampilan dimana saat user menjalankan aplikasi, maka user akan langsung diarahkan ke halaman Main Menu. Untuk melihat Interface Main Menu, perhatikan Gambar 4.1:

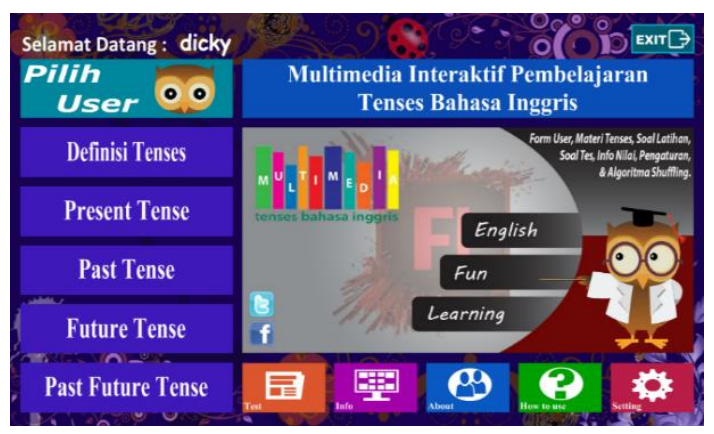

Gambar 8. Tampilan main menu

Dari Gambar 8, diketahui interface Main Menu menyajikan tombol menu kelola user (pilih user), pilih materi, tes (test), lihat nilai (info), lihat pembuat (about), panduan (how to use), kelola sistem (setting), dan tombol exit. Serta beberapa konten grafis tahapan material collecting yang dimasukkan kedalam halaman.

b. Interface Kelola User (Pilih User)

Tampilan dimana saat user, menekan tombol menu Pilih User untuk membuat dan mengahapus username. Interface dari menu Kelola User dapat dilihat pada Gambar 9: 


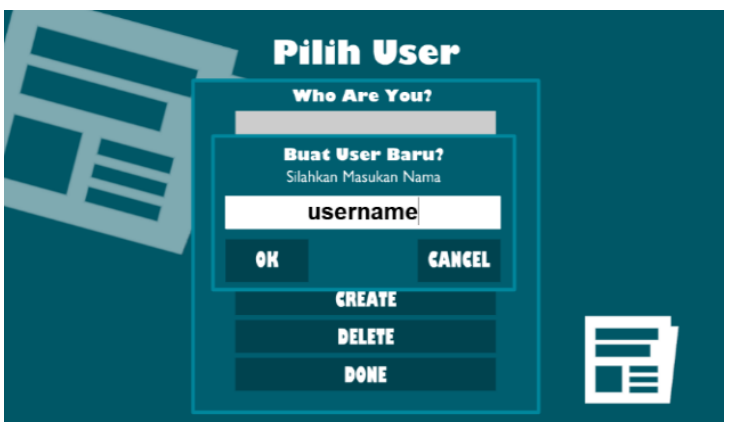

Gambar 9. Tampilan pilih user

c. Interface Materi Tenses

Tampilan dimana user menekan tombol merti tenses yang dipilihnya. Interface dari halaman materi tenses, dapat dilihat pada Gambar 10:

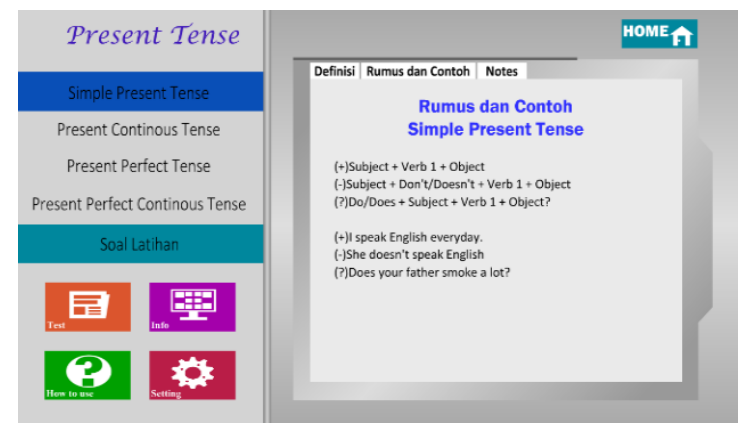

Gambar 10 Tampilan materi tenses

d. Interface Lihat Nilai (Info)

Tampilan dimana user ingin melihat histori nilai soal latihan dan tes, dengan menekan tombol Menu Info. Interface lihat nilai dapat dilihat, pada Gambar 11:

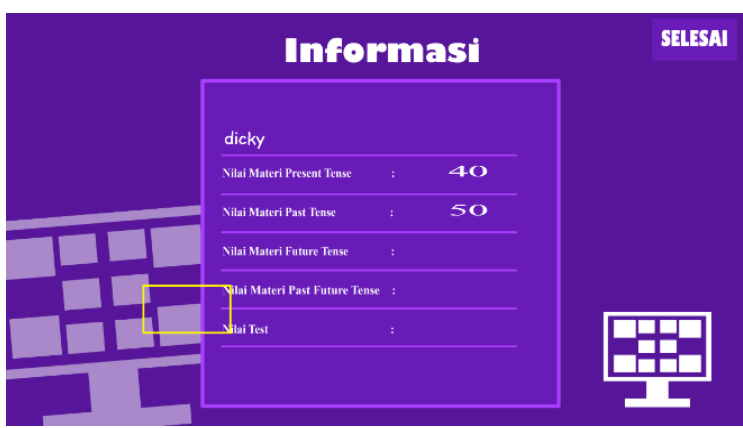

Gambar 11. Tampilan lihat nilai

\section{Pengujian Algoritma Fisher-Yates Shuffle}

Pengujian Algoritma Fisher-Yates Shuffle dilakukan, untuk melihat kinerja dari algoritma acak (shuffling) dalam mengacak array soal yang dipanggil dari bank soal .xml. Pengujian dilakukan dengan simulasi pengerjaan soal, perhatikan Gambar 12:

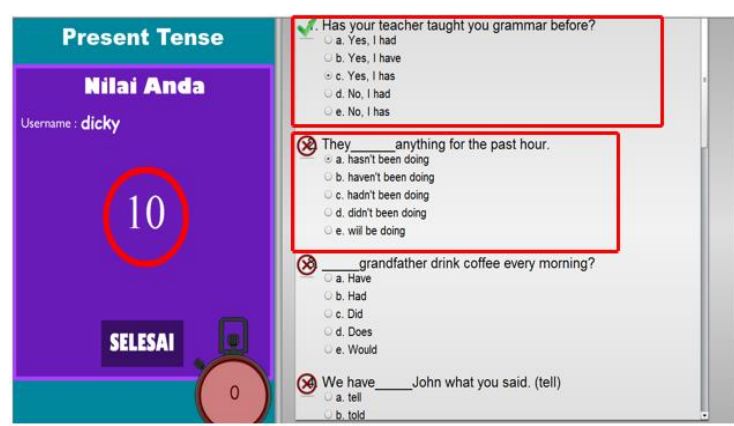

Gambar 12. Simulasi pengerjaan soal

Dari Gambar 12, telah dilakukan pengujian untuk melihat hasil kinerja dari algoritma Fisher-Yates Shuffle dengan melihat output hasil compile Aplikasi pada saat proses run. Urutan yang ditampilkan lembar soal disesuaikan dengan urutan array pada layar output dan urutan bank soal $\mathrm{xml}$. Perhatikan Gambar 13:

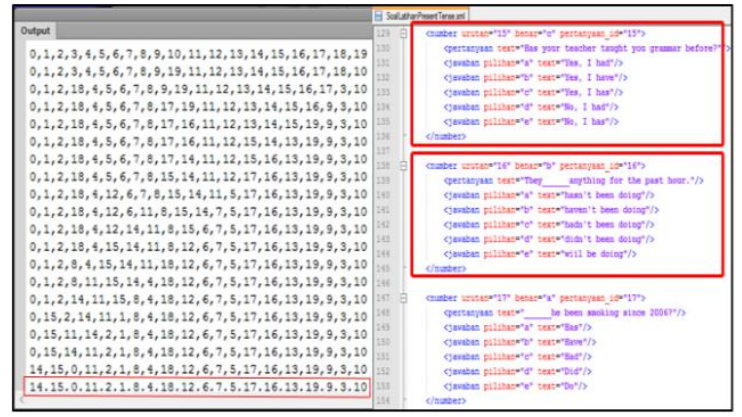

Gambar 13 Tampilan Output Array Aplikasi

Dari Gambar 13, setelah melakukan proses acak (shuffling) array sebanyak range 20 (jumlah soal latihan). Dapat dilihat posisi array pada output, memiliki kesamaan dengan posisi soal pada bank soal $x m l(n+1)$. Urutan array terakhir pada output inilah yang ditampilkan pada form soal (lihat Gambar 4.5).

Telah dilakukan pengujian lain, untuk melihat perpindahan step by step array yang berpindah posisi. Namun masih tetap dengan file xml yang memiliki jumlah soal sebanyak 20 bauh. Perhatikan Gambar 14: 


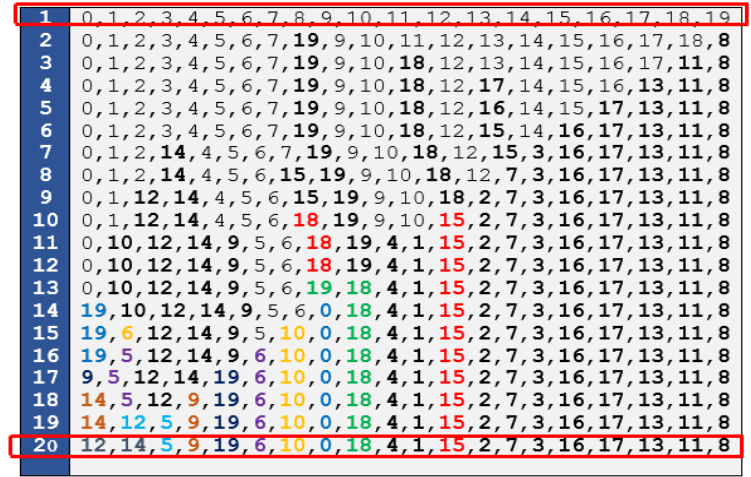

Gambar 14. Output perpindahan posisi array

Dari Gambar 14, dapat dilihat perpindahan posisi array yang terjadi. Posisi array yang sudah ditukar dengan array lain akan terus tetap ditukar, dan tidak terpengaruh oleh posisi array lain yang belum ditukar sampai pertukaran selesai dilakukan sebanyak 20 kali (disesuaikan dengan banyaknya jumlah soal). Urutan array di posisi ke-20 sudah berbeda jauh dengan urutan awal sebelum di acak (suffling).

Dari 20 array yang di shuffling, telah dilakukan pengujian sebanyak 10 kali percobaan untuk mengetahui permutasi yang dihasilkan. Pada tabel urutan soal, array akan ditambahkan 1 atau $(n+1)$, agar mempermudah memahami pengacakan urutan soal. Perhatikan Gambar 15:

\begin{tabular}{|c|c|c|c|c|c|c|c|c|c|c|c|}
\hline & \multicolumn{11}{|c|}{ Permutasi } \\
\hline & & 1 & 2 & 3 & 4 & 5 & 6 & 7 & 8 & 9 & 10 \\
\hline & 1 & 13 & 19 & 10 & 16 & 2 & 9 & 5 & 13 & 6 & 7 \\
\hline & 2 & 15 & 16 & 2 & 11 & 1 & 8 & 12 & 2 & 20 & 12 \\
\hline & 3 & 6 & 11 & 4 & 13 & 6 & 19 & 20 & 20 & 16 & 13 \\
\hline & 4 & 10 & 8 & 18 & 14 & 3 & 2 & 19 & 18 & 15 & 6 \\
\hline & 5 & 20 & 12 & 16 & 5 & 14 & 10 & 11 & 10 & 14 & 3 \\
\hline $\mathbf{U}$ & 6 & 7 & 7 & 20 & 19 & 12 & 12 & 2 & 6 & 7 & 19 \\
\hline $\mathbf{R}$ & 7 & 11 & 4 & 15 & 12 & 17 & 15 & 14 & 3 & 17 & 9 \\
\hline $\mathbf{U}$ & 8 & 1 & 9 & 11 & 1 & 13 & 16 & 18 & 16 & 19 & 15 \\
\hline $\mathbf{T}$ & 9 & 19 & 5 & 3 & 9 & 18 & 11 & 13 & 15 & 12 & 5 \\
\hline $\mathbf{A}$ & 10 & 5 & 13 & 12 & 17 & 5 & 20 & 4 & 8 & 11 & 2 \\
\hline $\mathbf{N}$ & 11 & 2 & 10 & 7 & 6 & 9 & 4 & 15 & 9 & 3 & 20 \\
\hline & 12 & 16 & 20 & 8 & 8 & 11 & 1 & 17 & 12 & 4 & 4 \\
\hline S & 13 & 3 & 18 & 17 & 15 & 20 & 3 & 7 & 11 & 10 & 14 \\
\hline $\mathbf{O}$ & 14 & 8 & 1 & 9 & 4 & 10 & 17 & 10 & 1 & 2 & 18 \\
\hline $\mathbf{A}$ & 15 & 4 & 3 & 19 & 10 & 16 & 13 & 16 & 17 & 8 & 16 \\
\hline $\mathbf{L}$ & 16 & 17 & 15 & 13 & 7 & 15 & 7 & 1 & 14 & 18 & 10 \\
\hline & 17 & 18 & 14 & 5 & 2 & 8 & 5 & 9 & 19 & 9 & 17 \\
\hline & 18 & 14 & 2 & 14 & 20 & 4 & 14 & 3 & 5 & 5 & 11 \\
\hline & 19 & 12 & 17 & 1 & 3 & 7 & 18 & 8 & 7 & 1 & 8 \\
\hline & 20 & 9 & 6 & 6 & 18 & 19 & 6 & 6 & 4 & 13 & 1 \\
\hline
\end{tabular}

Gambar 15. Hasil Pengujian acak (shuffling) Soal

Dari Gambar 15, dapat dilihat 10 permutasi acak (shuffling) hasil percobaan.
Algoritma Fisher-Yates Shuffle menghasilkan urutan soal teracak, dan dari hasil 10 kali shuffling tersebut tidak ada urutan soal yang sama.

\section{Pengujian Alpa (Black Box Testing)}

Pengujian dilakukan terhadap aplikasi untuk memastikan bahwa aplikasi dapat berjalan dengan benar sesuai dengan kebutuhan dan tujuan yang diharapkan. Pengujian ini dilakukan secara black box yaitu pengujian yang berfokus pada persyaratan fungsional perangkat lunak. Akan dijelaskan pada Tabel 4.1:

Tabel 2. Uji Menu Aplikasi Multimedia

\begin{tabular}{|c|c|c|c|c|}
\hline \multirow{2}{*}{ No } & \multirow{2}{*}{ SKENARIO } & \multicolumn{2}{|c|}{ HASIL } & \multirow{2}{*}{ KETERANGAN } \\
\hline & & SUKSES & GAGAL & \\
\hline 1 & Main Menu & $\sqrt{ }$ & & \\
\hline 2 & Menu Pilih User & $\sqrt{ }$ & & \\
\hline 3 & \begin{tabular}{|l} 
Pilih Materi Tenses \\
\end{tabular} & $\sqrt{ }$ & & \\
\hline 4 & Soal Latihan & $\sqrt{ }$ & & \\
\hline 5 & Menu Test & $\sqrt{ }$ & & \\
\hline 6 & Menu Info & $\sqrt{ }$ & & \\
\hline 7 & Menu About & $\sqrt{ }$ & & \\
\hline 8 & Menu How to Use & $\sqrt{ }$ & & \\
\hline 9 & Menu Setting & $\sqrt{ }$ & & \\
\hline 10 & Exit & $\sqrt{ }$ & & \\
\hline
\end{tabular}

\section{PENUTUP}

\section{Kesimpulan}

Setelah melakukan penelitian dalam skripsi ini, penulis dapat mengambil kesimpulan sebagai berikut:

a. Aplikasi Multimedia Tenses Bahasa Inggris ini, dapat dibangun menggunakan Adobe Flash CS6 dengan bahasa pemrograman ActionScript3.0. Dapat dikoneksikan dengan bank soal, menggunakan format penyimpanan data standar berbasis XML (eXtensible Markup Language). Untuk konten Multimedia yang disajikan seperti audio, gambar, dan animasi dapat dibuat dengan software pendukung Adode Family (Photoshop CS6, Illustrator CS6, dan Audtion CS6).

b. Algoritma Fisher-Yates Shuffle, dapat digunakan untuk mengacak (shuffling) data berupa soal dari file $X M L$. Dengan mengacak urutan array yang dipanggil oleh bahasa pemrograman ActionScript3.0 dari bank soal .xml. Array yang yang sudah dipindahkan pada setiap tahapan (step) berdasarkan jumlah range, disimpan ke temporary array sementara sampai range array yang ditentukan bernilai nol. Maka akan 
terlihat urutan array di awal akan berbeda dengan urutan array di akhir. Meskipun menggunakan skala range 1$N$, serta nilai $k$ ditentukan berdasarkan range (jumlah) soal. Namun urutan soal berikutnya tidak bisa ditebak, karena algoritma Fisher-Yates Shuffle menggunakan math random untuk mengubah urutan array yang dipanggil.

\section{Saran}

Berdasarkan hasil penelitian dapat diperoleh saran sebagai berikut:

a. Dari segi Multimedia, aplikasi ini sudah memenuhi unsur multimedia sebagai Content Production (teks, audio, graphics, animation, video dan interactivity). Namun untuk segi materi Bahasa Inggris, perlu dilengkapi menjadi English Grammar dan tidak sebatas materi Tenses.

b. Untuk penelitian lebih lanjut, Aplikasi Multimedia Interaktif ini dapat dikembangkan lagi menjadi aplikasi pembelajaran materi lain (Reusability).

\section{DAFTAR PUSTAKA}

[1] Ade-Ibijola, Abejide Olu. 2012. A Simulated Enhancement of Fisher-Yates Algorithm for Shuffling in Virtual Card Games using Domain-Specific Data Structures, International Journal of Computer Applications.

[2] All English Tenses (Revision).

http://www.anglo-

link.com/index.php?/online lesso ns/video lessons

(diakses tanggal 11 agustus 2014, 01:20)

[3] Ambler, S.W., 2005, The Elements of UML 2.0 Style, Cambridge University Press, Cambridge.

[4] Arsyad, Azhar. 2007. Media

Pembelajaran. Jakarta: PT Rajagrafindo Persada.

[5] Binanto, I., 2010, Multimedia Digital Dasar Teori dan Pengembangannya, Penerbit Andi, Yogyakarta.
[6] Black, Paul E. (2005-12-19).

"Fisher-Yates shuffle". Dictionary of

Algorithms and Data

Structures. National Institute of

Standards and Technology.

Retrieved 2007-08-09. (diakses tanggal 22 september 2013, $22: 52)$

[7] Durstenfeld, Richard (July 1964).

"Algorithm 235: Random

permutation". Communications of the ACM 7 (7): 420. (diakses tanggal 22 september 2013, 22:52)

[8] Fisher, R.A.; Yates, F. (1948)

[1938]. Statistical tables for biological,

agricultural and medical research (3rd ed.). London: Oliver \& Boyd. pp. 26-27. (diakses tanggal 22 september 2013, 22:52)

[9] Fisher-Yates Shuffle. http://en.algoritmy.net/article/436 76/Fisher-Yates-shuffle (diakses tanggal 22 september 2013, 22:52)

[10] Herlawati, P.P.W., 2011, Menggunakan UML, Penerbit Informatika, Bandung.

[11] Hughes, A., 2011, The Online English Grammar, http://www.english4today.com/gra

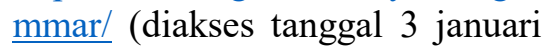
2014, 10:30) 